\title{
RP-HPLC METHOD DEVELOPMENT AND VALIDATION OF NEVIRAPINE IN BULK AND DOSAGE FORMS
}

\author{
Manasa Merugu*, A. Ramya, Ameena Shireen, \\ Ankit Kumar Varma and AP. Nirmala
}

Department of Pharmaceutical Analysis, Pulla Reddy Institute of Pharmacy, Domadugu (V), Gummadidala (M), Sangareddy(D), Hyderabad, Telangana, India.

\begin{abstract}
An economic, accurate, precise and reproducible Reverse Phase High Performance Liquid Chromatographic (RP-HPLC) method has been developed and validated for Nevirapine. It is an anti-viral drug and it is belongs to the class of non nucleoside reverse transcriptase inhibitor (NNRITS) available in market in the form of tablets and oral suspension. The quantification of Nevirapine was carried out by using Agilent 150 column as stationary phase with the mobile phase consisting of methanol and HPLC grade water in the ratio of $50: 50(\mathrm{v} / \mathrm{v})$ which resulted in best sensitivity. The mobile phase was pumped at a rate of $1 \mathrm{ml} / \mathrm{min}$. The drug was identified with PDA detector at $229.0 \mathrm{~nm}$. The processed method was validated in terms of linearity, range, precession, robustness, accuracy as per ICH guidelines. The validation of processed method was verified by recovery studies and can be applicable in routine determination of Nevirapine in pharmaceutical formulations.
\end{abstract}

Keywords: Nevirapine, non nucleoside reverse transcriptase inhibitor and RP-HPLC.

\section{INTRODUCTION $^{1-17}$}

Nevirapineis a anti-viral medicine belonging to the class of non nucleoside reverse transcriptase inhibitor (NNRITS) with activity against the human immunodeficiency virus type-1 (HIV-1). It prevents the multiplication of HIV in human body. Nevirapine binds directly with reverse transcriptase and blocks the RNA dependent and DNA dependent, DNA polymerase activities by causing a disruption of enzyme's catalytic site. Thus inhibits the cycle DNA synthesis and prevents the viral replication. Mono therapy of these NNRITS leads to resistance due to single mutation in viral reverse transcriptase enzyme. Hence, they should be taken in combination with other HIV medication such as Retonavir or videx. Nevirapine is well absorbed orally and it has the bioavailability about $90-95 \%$. It is a lipophilic drug and widely distributed throughout the body. It is metabolized in liver by CYP3A4 enzyme and excreted in urine. The half life of drug is 25-30 hours.

Chemically Nevirapine is 2-cyclopropyl-7methyl-2,4,9.15tetraaztricyclo

$\left[9.4 \cdot 0.0^{3}\right.$,] pentadeca-1(11),3,5,7,1,2,14-hexane-10one.chemical formula is $\mathrm{C}_{15} \mathrm{H}_{14} \mathrm{~N}_{4} \mathrm{O}$ with the molecular weight of 266.2979. The trade name of Nevirapine is Viramune.

\section{Structure}

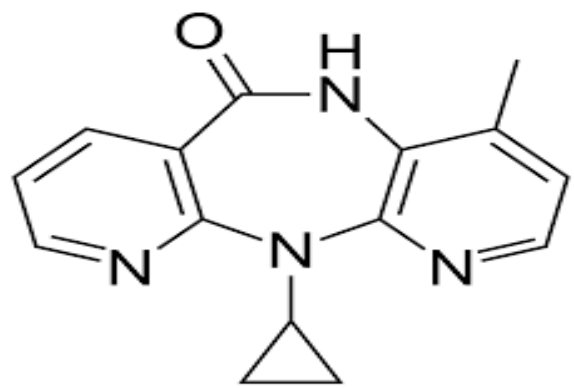

Fig. 1: Structure of Nevirapine

In this research work we have developed, optimized, and validated the method using RPHPLC. Drug was assayed by validated method. The main objective of this method is to develop time saving and cost effective. 


\section{MATERIALS AND METHOD}

\section{CHEMICALS AND REAGENTS}

Reference standard was obtained from sigma Aldrich laboratories. The formulation used for assay is Nevirapine manufactured by Viramune and solvents used in this method were acetonitrile and HPLC grade water.

\section{INSTRUMENTATION}

Method development and validation was carried out by RP-HPLC (Shimadzu) with PDA detector module with auto-sampler. Column used was Agilent Eclipse XBD (150*4.6* $5 \mu \mathrm{m})$, and data recorded using LC Solutions software.

\section{DILUENT}

Methanol: Water (50:50).

\section{PREPARATION OF STANDARD}

Weigh accurately about $100 \mathrm{mg}$ of drug and transfer it into $10 \mathrm{ml}$ volumetric flask and make up the volume up to $10 \mathrm{ml}$ using diluent and sonicated for 5 minutes. Pipette out $1 \mathrm{ml}$ of above solution into $10 \mathrm{ml}$ volumetric flask, make up the volume with diluent. Obtained standard concentration is $100 \mu \mathrm{g} / \mathrm{ml}$.

\section{PREPARATION OF SAMPLE}

Take 20 tablets and triturate it. Weigh accurately equivalent to $100 \mathrm{mg}$ of tablet powder and transfer it into $10 \mathrm{ml}$ volumetric flask and make up the volume up to $10 \mathrm{ml}$ using diluent and sonicated for 5 minutes. Pipette out $1 \mathrm{ml}$ of above solution into $10 \mathrm{ml}$ volumetric flask, make up the volume with diluent.

\section{METHOD OPTIMIZATION}

Based on the literature of Nevirapine and its combinations, one method was developed after conducting several trials and developed method was optimized.

\section{VALIDATION}

The developed method was validated foe different parameters like system suitability, Linearity, accuracy, precision, LOD, LOQ, and Robustness as per ICH guidelines.

\section{SYSTEM SUITABILITY}

By injecting it six times into the system, the chromatograms of $100 \mu \mathrm{g} / \mathrm{ml}$ were analyzed. Form chromatogram the system suitability parameters like plate count, tailing factor, capacity factor and reproducibility were determined.

\section{LINEARITY}

A series of solutions were prepared at concentration levels as $50 \mu \mathrm{g} / \mathrm{ml}, 75 \mu \mathrm{g} / \mathrm{ml}$, $100 \mu \mathrm{g} / \mathrm{ml}, \quad 125 \mu \mathrm{g} / \mathrm{ml}$, and $150 \mu \mathrm{g} / \mathrm{ml}$. A
$10 \mu$ lvolume from each concentration of solutions were injected thrice into the HPLC system. Chromatograms were recorded under optimized chromatographic conditions. A graph was plotted considering peak areas on $\mathrm{Y}$-axis and concentration on $\mathrm{X}$-axis. The linear equation, $\mathrm{Y}$-intercept, slope of regression line and regression constant $\left(r^{2}\right)$ were calculated.

\section{PRECISION}

Repeatability or intra-day precision: The peak areas of $100 \mu \mathrm{g} / \mathrm{ml}$ were analyzed on the same day by injecting it six times into the system. The chromatogram was recorded and RSD was calculated.

\section{ACCURACY}

A series of solutions were prepared in triplicate by spiking the known standard concentrations of Nevirapinein the range of $50-150 \%$ on the tablet solution and analyzed. The accuracy of method was provided at three different concentration levels at 50,100 , and $150 \mu \mathrm{g} / \mathrm{ml}$ of Nevirapine standard. The percentage recoveries of three different concentrations were found to be within the range of 98 to 102 $\%$ as per $I C H Q_{2} R_{1}$ guidelines.

\section{LIMIT OF DETECTION AND LIMIT OF QUANTITATION}

LOD and LOQ can be calculated based on the signal to noise ratio approach, visual evaluation and standard deviation of the response and slope of the calibration curve. The slope (S) is calculated from the equation of straight line in calibration curve of the analyte. The standard deviation $(\sigma)$ is calculated based on its blank response or they-intercepts of regression line. Formulas were given below

$$
\begin{aligned}
& L O D=(3.3 \times \text { SD }) / \text { Slope } \\
& L O Q=(10 \times \text { SD }) / \text { Slope }
\end{aligned}
$$

\section{ROBUSTNESS\& RUGGEDNESS}

The robustness of a method is its ability to remain unaffected under changes in parameters. Robustness was carried out by altering the flow rate $( \pm 0.2 \mathrm{ml} / \mathrm{min})$ and mobile phase (60:50 \& 50:60). The standard solution comprising of Nevirapine $(100 \mu \mathrm{g} / \mathrm{ml})$ was injected six times and the \%RSD was calculated for the resultant area of the peak.

\footnotetext{
ASSAY

Twenty tablets of Nevirapine were taken and powdered, Weigh accurately equivalent about $10 \mathrm{mg}$ of lable drug and transferred into 100 $\mathrm{ml}$ volumetric flask to it added $30 \mathrm{ml}$ of diluent, sonicated 5 minutes and finally made up the volume with diluent. The solution was then
} 
injected into the HPLC system. The sample was prepared in triplicates.

$\%$ Assay =

(Area of unknown X Conc of standard)

X $\quad \times 100$

(Area of standard X Conc of unknown)

\section{RESULTS AND DISCUSSION}

OPTIMIZATION OF CHROMATOGRAPHIC

Developed method was optimized for different parameters.

Parameters were given in Table.1 and Fig No 2.

\section{SYSTEM SUITABILITY}

The percentage area of Relative Standard deviation (RSD) from six replicate injections was found below2.0\% (diluted standard solution, $100 \mu \mathrm{g} / \mathrm{ml}$ of NEVIRAPINE). Low values of RSD of replicated injections indicate that the system is precise. The results are presented in Table2.

\section{LINEARITY}

The calibration curve was made by plotting the concentration on $\mathrm{X}$-axis against peak area on Y-axis. A series of Nevirapine standard solution were prepared in the range of 50 $\mu \mathrm{g} / \mathrm{ml}-150 \mu \mathrm{g} / \mathrm{ml}$. The correlation coefficient of the curve was found to be0.998with a regression equation of $Y=46503 x+41001$. This is shown in figure no 3 and results were given in table no 3 .

\section{PRECISION}

Repeatability or intra-day precision: The peak areas of $100 \mathrm{ug} / \mathrm{ml}$ were analyzed on the same day by injecting it six times into the system. $\%$ RSD was calculated. The \%RSD was found to be 0.025 . Results were given in table no:4.

\section{ACCURACY}

Recovery of Nevirapine was found to be $98.0 \%$ to $102.0 \%$. The summary of $\%$ recovery of Nevirapine was mentioned in Table 5.

\section{LIMIT OF DETECTION AND LIMIT OF QUANTITATION}

LOD and LOQ were calculated from linearity graph. The limit of Detection and limit of Quantification were found out to be 0.032 $\mathrm{ng} / \mathrm{ml}$ and $0.098 \mathrm{ng} / \mathrm{ml}$ respectively.

\section{ROBUSTNESS AND RUGGEDNESS}

Robustness studies were performed by changing the flow rate $( \pm 2 \mathrm{ml} / \mathrm{min})$, column temperature $\left( \pm 5^{\circ} \mathrm{C}\right)$ and mobile phase ratio. No significant effect was observed on system suitability parameters deliberate change such as resolution, RSD, tailing factor, or the theoretical plates of Nevirapine. Thus, the method was found to be robust with respect to variability in applied conditions.

\section{ASSAY}

Tablet solution was injected into the HPLC system for three times and \% assay of drug was found to be99.2\%. These results were tabulated in Table No 6.

\section{CONCLUSION}

An easy, rapid and efficient Reverse-Phase HPLC method was developed for quantitative estimation of Nevirapine in drug product and drug substance. The method was validated as per ICH Q2 (R1) guidelines. A precise, accurate, linear, robust and rugged method was found during validation. Limits of detection $0.032 \mathrm{ng} / \mathrm{ml}$ and limits of quantification $0.098 \mathrm{ng} / \mathrm{mlalso}$ determined. By performing the assay of Viramune tablet the percentage purity was found to be $99.2 \%$. Hence it was concluded that this method is useful for the determination of both pharmaceutical substance and pharmaceutical product.

\section{ACKNOWLEDGEMENTS}

We are thankful to Pulla Reddy Institute of Pharmacy (PRIP) and to the Department of Pharmaceutical Analysis Quality Assurance for providing the utmost facilities such as lab, equipment and chemicals to succeed our work.

\section{CONFLICT OF INTEREST}

The authors have no conflict of interests to disclose other thanwhat has been acknowledged above. 
Table 1: Optimized conditions

\begin{tabular}{|c|c|c|}
\hline S.NO & Parameter & Results \\
\hline 1 & Mobile phase & Methanol and water(50:50) \\
\hline 2 & Stationary phase & Agilant 150 column \\
\hline 3 & $\lambda$ max & $229 \mathrm{~nm}$ \\
\hline 4 & Run time & $4.034 \mathrm{~min}$ \\
\hline 5 & Injection volume & $20 \mu \mathrm{l}$ \\
\hline 6 & Flow rate & $1.0 \mathrm{ml} / \mathrm{min}$ \\
\hline 7 & Area & 1823653 \\
\hline 8 & Height & 102883 \\
\hline 9 & Tailing factor & 0.995 \\
\hline
\end{tabular}

Table 2: System Suitability Results

\begin{tabular}{|c|c|c|}
\hline S.no & Area & Tailing Factor \\
\hline 1 & 1824593 & 0.995 \\
\hline 2 & 1823653 & 0.984 \\
\hline 3 & 1824534 & 0.989 \\
\hline 4 & 1823892 & 0.993 \\
\hline 5 & 1823633 & 0.995 \\
\hline 6 & 1823625 & 0.996 \\
\hline Avg & \multicolumn{2}{|c|}{1823988.333} \\
\hline SD & \multicolumn{2}{|c|}{456.809661} \\
\hline \%RSD & \multicolumn{2}{|c|}{0.02504455} \\
\hline
\end{tabular}

Table 3: Linearity Results

\begin{tabular}{|c|c|c|}
\hline CONC & AREA & AVERAGE \\
\hline \multirow{3}{*}{$50 \mu \mathrm{g} / \mathrm{ml}$} & 898248 & \multirow{3}{*}{898881.3} \\
\hline & 899148 & \\
\hline & 899248 & \\
\hline \multirow{3}{*}{$75 \mu \mathrm{g} / \mathrm{ml}$} & 1289784 & \multirow{3}{*}{1289847.3} \\
\hline & 1289934 & \\
\hline & 1289824 & \\
\hline \multirow{3}{*}{$100 \mu \mathrm{g} / \mathrm{ml}$} & 1824593 & \multirow{3}{*}{1824260} \\
\hline & 1823653 & \\
\hline & 1824534 & \\
\hline \multirow{3}{*}{$125 \mu \mathrm{g} / \mathrm{ml}$} & 2287213 & \multirow{3}{*}{2287146.3} \\
\hline & 2286913 & \\
\hline & 2287313 & \\
\hline \multirow{3}{*}{$150 \mu \mathrm{g} / \mathrm{ml}$} & 2725374 & \multirow{3}{*}{2725380.6} \\
\hline & 2725294 & \\
\hline & 2725474 & \\
\hline
\end{tabular}

Table 4: Precision Results

\begin{tabular}{|c|c|c|}
\hline S.No & RT (min) & AREA \\
\hline 1 & 4.034 & 1824593 \\
\hline 2 & 4.034 & 1823653 \\
\hline 3 & 4.034 & 1824534 \\
\hline 4 & 4.034 & 1823892 \\
\hline 5 & 4.034 & 1823633 \\
\hline 6 & 4.034 & 1823625 \\
\hline \multicolumn{2}{|r|}{ Avg } & 1823988.3 \\
\hline \multicolumn{2}{|r|}{ SD } & 456.80 \\
\hline \multicolumn{2}{|c|}{$\%$ RSD } & 0.025 \\
\hline
\end{tabular}

Table 5: Accuracy Results

\begin{tabular}{|c|c|c|c|c|c|c|}
\hline Conc Level & Area & STD Area & $\begin{array}{l}\text { Conc } \\
\text { added }\end{array}$ & $\begin{array}{c}\text { Conc } \\
\text { Recovery }\end{array}$ & $\%$ Recovery & Avg \\
\hline \multirow{3}{*}{$50 \%$} & 898248 & 1823988 & 50 & 49.25 & 98.49 & \multirow{3}{*}{98.56} \\
\hline & 899148 & 1823988 & 50 & 49.30 & 98.59 & \\
\hline & 899248 & 1823988 & 50 & 49.30 & 98.60 & \\
\hline \multirow{3}{*}{$100 \%$} & 1824593 & 1823988 & 100 & 100.03 & 100.03 & \multirow{3}{*}{100.01} \\
\hline & 1823653 & 1823988 & 100 & 99.98 & 99.98 & \\
\hline & 1824534 & 1823988 & 100 & 100.03 & 100.03 & \\
\hline \multirow{3}{*}{$150 \%$} & 2725374 & 1823988 & 150 & 149.42 & 99.61 & \multirow{3}{*}{99.61} \\
\hline & 2725294 & 1823988 & 150 & 149.41 & 99.61 & \\
\hline & 2725474 & 1823988 & 150 & 149.42 & 99.62 & \\
\hline
\end{tabular}


Table 6: Assay Results

\begin{tabular}{|c|c|c|}
\hline S.No & Sample Area & Standard Area \\
\hline 1 & 1809893 & 1824593 \\
\hline 2 & 1809653 & 1823653 \\
\hline 3 & 1809534 & 1824534 \\
\hline 4 & 1809892 & 1823892 \\
\hline 5 & 1809633 & 1823633 \\
\hline 6 & 1809625 & 1823625 \\
\hline Avg & 1809705 & 1823988.3 \\
\hline \% Assay & \multicolumn{2}{|c|}{99.2} \\
\hline
\end{tabular}

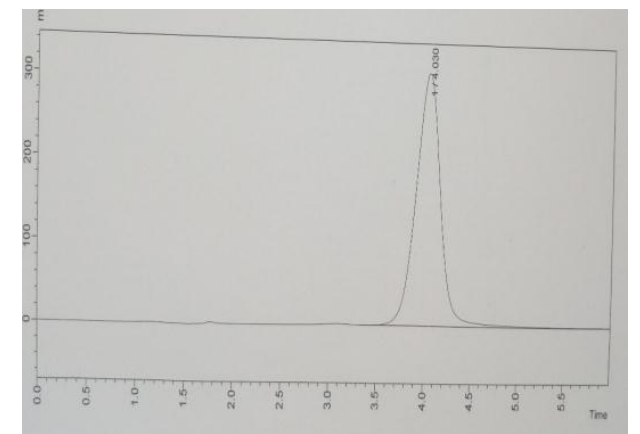

Fig. 2: Optimized Chromatogram of Nevirapine

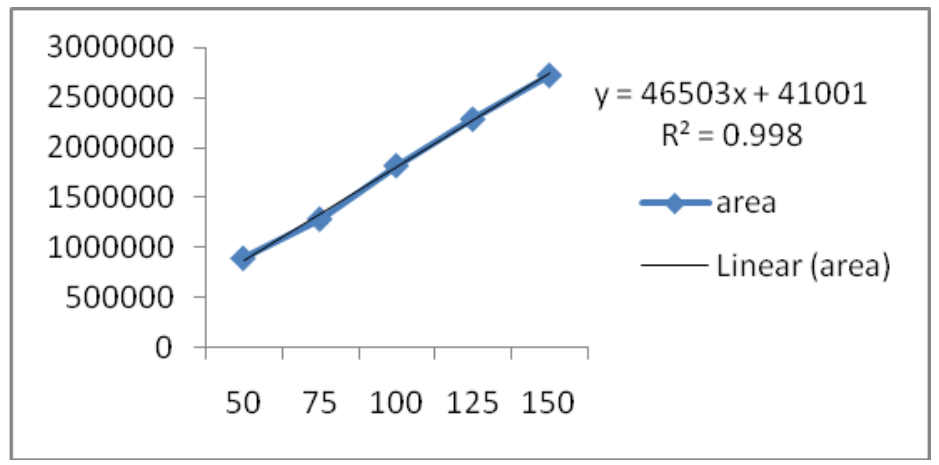

Fig. 3: Linearity Graph of Nevirapine

\section{REFERENCES}

1. Erik Gregersen. Revised article on chromatography by, Encyclopedia Britannica.17 Nov 2016.

2. Kumar SD and Kumar. Importance of RP-HPLC in analytical methoddevelopment- A review: A review. Int $\mathrm{J}$ Pharm Sci Res. 3(12):4626-4633.

3. Skoog DA and Leary JJ. Principles of Instrumental Analysis. 1992;4.

4. Sowmyalakshmi Venkataraman and Merugu Manasa. Forced degradation studies:Regulatory guidance, characterization of drugs, and their degradation products - a review. Drug invention today. 2018;10(2):137-138.
5. Available at https://www.drugbank.ca/drugs/DB002 38

6. Available at https://www. accessdata. fda.gov/ drugsatfda_docs/ label/2005/20636s025,20933s014lbl.p df.

7. Phani RSCH, Prasad KRS and Useni Reddy Mallu. High resolution RPHPLC method for the determination of nevirapine and associated impurities. Oriental Journal of chemistry 2016;32(2).

8. Prasada Rao $\mathrm{CH}$, Channa basavaraj KP and Lakshmi Aswini G. Development andvalidation of RPHPLC method for the estimation of 
Nevirapine in bulk drug andtablets, Journal of Pharmaceutical Sciences and Research. 2009;1(2).

9. Purnima Hamrapurkar, Mitesh Phale, Priti Patil, and Nitul Shah. Method for determination of Nevirapine in human plasma by high performance liquidstability indicating method development and validation of Nevirapine by RP-HPLC. International Journal of Pharm Tech Research. 2010;2(2):1316-1324.

10. Venkata Kumar $\mathrm{CH}$, Ananth Kumar D and Seshagiri Rao JVLN. A new validated RP- HPLC method for the determination of Nevirapine in human plasma. E-Journal of Chemistry. 2010; 7(3):821-826.

11. Nandi U, Das A, Roy B, Choudhury H, Gorain B and Pal TK. Development and validation of an HPLC-UV method for simultaneous determination of zidovudine, lamivudine, and
Nevirapine in human plasma and its application to pharmacokinetic study in human volunteers. Drug Test Anal. 2013;5(6):485-91.

12. Dharmaraj Santhosam S, Adiyaman E and Senthil kumar M. Development and validation of RP-HPLC method for the simultaneous estimation of Lamivudine, Zidovudine and Nevirapine from bulk and tablet dosage form. Internationaljournal ofpharmaceutical and chemical sciences. 2013;2(4):1883-1887.

13. Som Shankar Dubey, and Mahesh Duggirala, Stability Indicating Method Development and validation of Lamivudine, Zidovudine. 2017;9(3):1626.

14. Available at www.science direct.com 18/9/09.

15. Available https://www.fda.gov/media/71724. 